\section{The pS-Activity Curve of a Serum Fraction IV-6-3 Studied with Butyrylcholine at $\mathrm{pS}$ above 3}

EDITH HEILBRON N

\section{Research Institute of National Defence, Dept. 1, Sundbyberg 4, Sweden}

Studies on the butyrylcholinesterase $N$ (BuChE) catalyzed hydrolysis of thiocholine esters ${ }^{1}$ performed in $0.1 \mathrm{M}$ potassium chloride, with the aid of an automatic recording titrator ${ }^{2}$ and using fraction IV. 6-3 obtained from retroplacentar serum (AB Kabi, Stockholm), gave results, which apparently did not follow the MichaelisMenten law. In no case could straight lines be obtained when, for example, according to Hofstee's ${ }^{3}$ variation of the Michaelis-Menten equation

$$
v=-\frac{v}{\mathrm{~S}} \times K_{\mathbf{M}}+V_{\mathrm{m}}
$$

enzyme activity $(v)$ was plotted against $v / \mathrm{S}(\mathrm{S}=$ conc. of the substrate). 'All $\mathrm{pS}$ activity curves showed a kind of S-shape, but the activity did not approach zero around substrate concentrations of $0.5 \times$ $10^{-3} \mathrm{M}$, as one would expect. The unexpected high reaction velocities at low substrate concentrations were shown not to depend upon spontaneous hydrolysis of the substrates or upon accelerating effects of potassium iodide (Fig. 1).
In order to find out, if the reason for the deviation from the Michaelis-Menten law was to be found in the enzyme preparation, it was decided to study a pS-activity curve with the same enzyme preparation and a wellknown substrate such as butyrylcholine iodide (BuChI). This was done at constant ionic strength $\mu=0.20$, $\mathrm{pH}=8.00$ and $25^{\circ} \mathrm{C}$. By means of introducing a second syringe in the automatic recording titrator, driven synchronously with the syringe containing the titrator (sodium hydroxide) and containing a BuChI solution of exactly the same concentration as the titrator (each mole of hydrolysed BuChI consumes one mole of sodium hydroxide), it was possible to keep the substrate concentration constant during the course of hydrolysis and thus to change a pseudo-first order reaction to $\mathbf{a}$ pseudo-zero order reaction. This method allowed studies of the hydrolysis down to about $10^{-6} \mathrm{M}$ solutions of substrate. The small amcunts of solutions from the syringes caused only insignificant changes in the ionic strength of the solution during the course of hydrolysis.

Enzyme: $25 \mathrm{mg}$ of serumfraction IV-6-3 were dissolved in $100 \mathrm{ml}$ of $0.1 \mathrm{M}$ potassium chloride. Titrator: $0.025 \mathrm{M}$ sodium hydroxide. Substrate solution: The second syringe contained a $0.025 \mathrm{M}$ solution of butyrylcholine iodide in distilled water. Substrate concentration and ionic strength: A substrate concentration range from $10^{-1} \mathrm{M}$ to $10^{-6} \mathrm{M}$ (in final solution) was studied. The ionic strength of the final

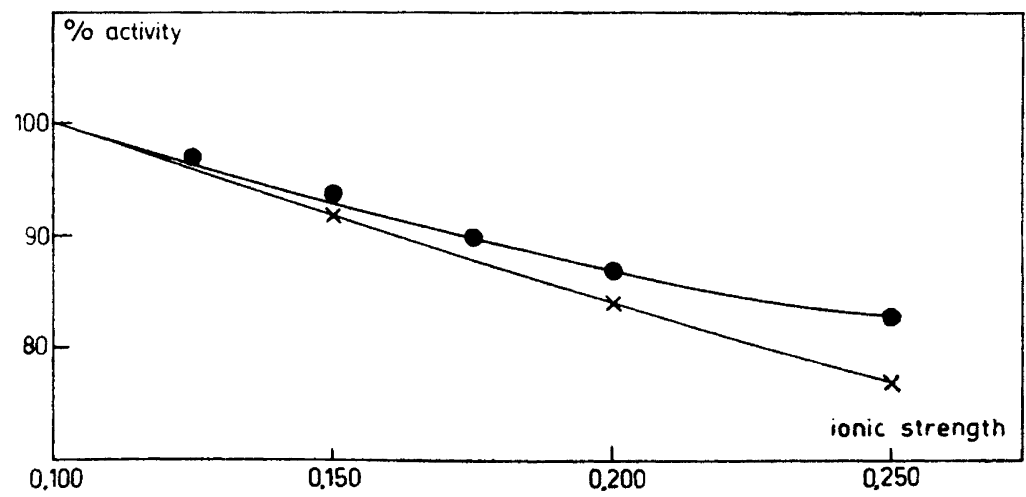

Fig. 1. Dependence of enzyme activity on ionic strength for the system potassium chloride -IV-6-3 - acetylthiocholine iodide (O) and potassium iodide-IV-6-3-acetylthiocholine iodide $(\times)$. Concentration of acetylthiocholine iodide $0.001 \mathrm{M}$.

Acta Chem. Scand. 12 (1958) No. 9 


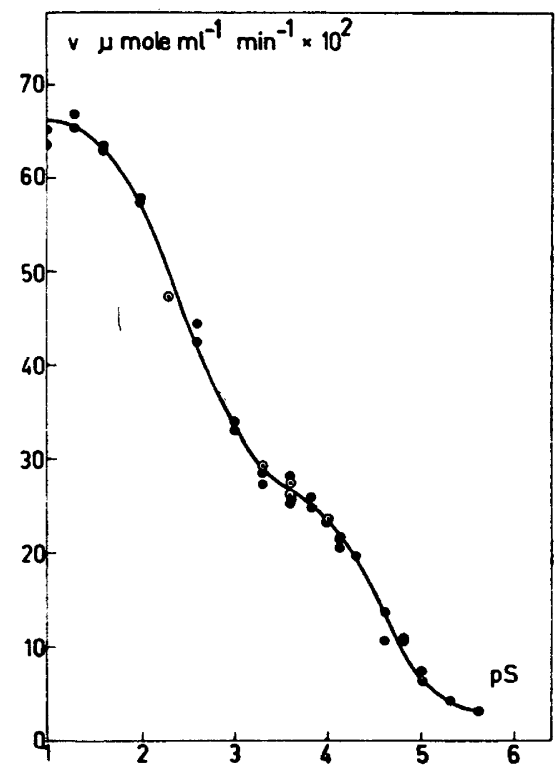

Fig. 2. pS-Activity curve for the system serum fraction IV-6-3-BuChI at $t=25^{\circ} \mathrm{C}$, ionic strength $\mu=0.20, \mathrm{pH}=8.00$. Substrate concentration kept constant by means of "double syringe" method.

solutions was kept at 0.20 by dissolving additional amounts of potassium iodide. Method: $37 \mathrm{ml}$ of $0.10 \mathrm{M}$ potassium chloride were added to the vessel. Substrate and potassium iodide were dissolved in this solution. The syringe containing the titrator was put into place and $\mathrm{pH}$ was adjusted to 8.00 . $3 \mathrm{ml}$ of enzyme solution were administered and $\mathrm{pH}$ was immediately again adjusted to 8.00 . The second syringe was put into place and hydrolysis was recorded during about $10 \mathrm{~min}$. Initial values were used for calculations.

Fig. 2 shows the curve obtained which gives the impression of 2 enzymes able to split BuChI. The second enzyme seems to have a very low substrate maximum, about $0.5 \times 10^{-3} \mathrm{M}$. Assuming that the second enzyme is of the BuChE type, thus not inhibited by excess of substrate, it was possible to obtain two straight lines, according to Hofstee's equation, as shown in Fig. 3. The lines were calculated by the method of least squares. From the line representing the second enzyme, the maximum activity for the second enzyme,

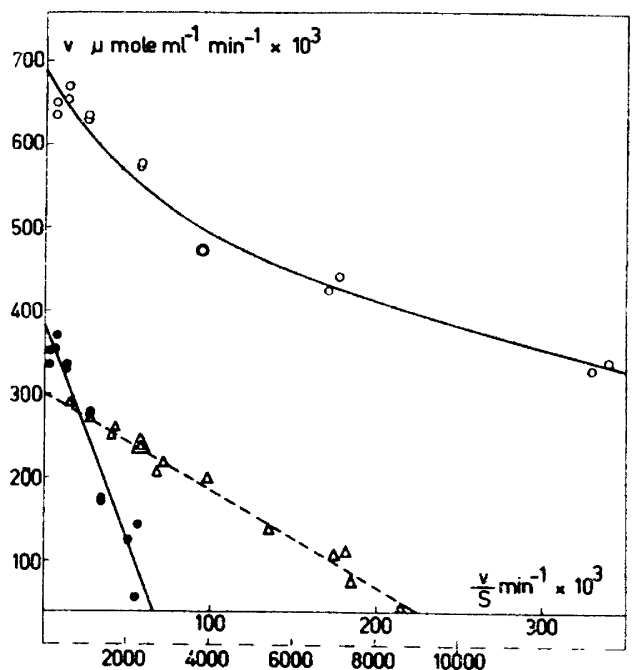

Fig. 3. Michaelis-Menten plot according to Hofstee. O, experimentally obtained curve; - first part of the curve minus maximum activity for the second part of the curve; $\triangle$, second part of the curve. Straight lines calculated by method of least squares.

$0.3 \mu$ mole $\mathrm{ml}^{-1} \mathrm{~min}^{-1}$, was calculated. This value was subtracted from the activity values of the first part of the experimentally obtained pS-activity curve. The last values belonging to the first part of this curve were subtracted by $0.29 \mu$ mole $\mathrm{ml}^{-1} \mathrm{~min}^{-1}$, as maximum activity does not seem to be reached at this point.

The possibility of two enzymes occurring in the preparation used is also indicated by earlier electrophoretic and chromatographic studies ${ }^{4}$ on fraction IV-6-3. Chromatograms on calcium phosphate showed always two peaks with cholinesterase activity.

My sincere thanks are due to Professor G. Ljunggren, Director of the Research Institute of National Defence, Dept. 1, for his kind interest in this work.

1. Heilbronn, E. Acta Chem. Scand. In press.

2. Larsson, L. and Hansen, B. Svensk Kem. Tidskr. 68 (1956) 521.

3. Hofstee, B. H. J. Science 116 (1952) 329

4. Malmström, B. G., Levin, Ö. and Boman, H. G. Acta Chem. Scand. 10 (1956) 1077.

Received October 22, 1958.

Acta Chem. Scand. 12 (1958) No. 9 